\title{
PROBLEMATYKA WCIELENIA SYNA BOŻEGO W „DIVINAE INSTITUTIONES” LAKTANCJUSZA
}

Tajemnica wcielenia Chrystusa była przedmiotem nie tylko wiary, ale i rozważań już najwcześniejszych pisarzy i Ojców Kościoła. Wystarczy tu bowiem przytoczyć stwierdzenia choćby św. Ignacego z Listu do Efezjan: „Bóg nasz bowiem, Jezus Chrystus, począł się w łonie Maryi zgodnie z planem Bożym, z rodu Dawida i z Ducha Świętego. On to urodził się i został ochrzczony, aby oczyścić wodę przez swoją mękę"1, albo wzmianki występujące w Homilii Paschalnej Melitona: „Zaiste, zrodzony jak Syn, prowadzony na rzeź jak baranek" ${ }^{2}$. Problematyka wcielenia była też od początku żywo dyskutowana i - jak dobrze wiadomo - budziła wiele kontrowersji, które w toku rozwoju doktryny chrześcijańskiej prowadziły do groźnych nieraz i mających tragiczne dla jedności Kościoła skutki herezji. Nic też dziwnego, że i Laktancjusz, który w swym najobszerniejszym dziele Divinae Institutiones chciał poruszyć wszystkie istotne dla nauki chrześcijańskiej zagadnienia, nie mógł i nie chciał pominąć milczeniem kwestii chrystologicznych, w tym również problemu wcielenia. W literaturze przedmiotu znajdujemy właściwie jedną tylko znaczniejszą publikację Mc Guckina na ten temat ${ }^{3}$, oraz krótką notę Grillmeiera w obszerniejszej pracy zbiorowej poświęconej problematyce chrystologicznej w dziełach Ojców Kościoła tamtych czasów ${ }^{4}$. U Laktancjusza znajduje ona swój wyraz w IV księdze wymienionego dzieła, zatytułowanej: De vera sapientia et religione. Ponieważ autor nasz mówi o dwukrotnych narodzinach Chrystusa, przy czym pierwszymi narodzinami nazywa zrodzenie Go z Ojca, a drugimi zrodzenie w ciele z Maryi, dlatego w naszej krótkiej analizie skoncentrujemy uwagę na powtórnym narodzeniu Chrystusa. Już w dziesiątym rozdziale II księgi swego dzieła stwierdza, że Syn Boży ,in figura hominis et conditione

${ }^{1}$ Epistula ad Ephesios 18, 2, SCh 10, 72-74, tłum. A. Świderkówna, BOK 10 (Pierwsi świadkowie, Kraków 1998), s. 118.

${ }^{2}$ Homilia paschalis 8, SCh 123, 64, tłum. A. Świderkówna, BOK 10, 309.

3 Por. Paul McGuckin, The Christology of Lactantius, „Studia Patristica” 17(1979) 813-820.

${ }^{4}$ Por. A. Grillmeier, Jesus Christus im Glauben der Kirche, Bd. I, Freiburg-Basel-Wien 1979, 326-345. 
mortali” zstąpił na ziemię, by pouczyć ludzi o sprawiedliwości, a człowiekowi, którego postać przybrał, przynieść nadzieję pokonania śmierci i uzyskania nagrody życia wiecznego" ". Fakt przyjścia Chrystusa na świat w ludzkim ciele znajduje potwierdzenie również w jedenastym rozdziale IV księgi, w którym pisze: ,renasci Eum denuo in carne praecepit et ipsi homini similem fieri, cui dux et comes et magister esset futurus"

Laktancjusz starannie zbiera świadectwa z Pisma Świętego odnoszące się do przyjścia na świat Chrystusa w ludzkim ciele, nie pomijając przy tym, co oczywiste, cytatów z Księgi Izajasza, mówiących o poczęciu Syna przez Dziewicę i nazwaniu Go Emmanuelem ${ }^{7}$. Sam zaś kluczowy cytat komentuje w następujący sposób: „Sed propheta declaravit hoc nomine, quod Deus ad homines in carne venturus esset" $"$. Przytacza jednak (z posiadanego przez siebie tekstu, który odbiega od dzisiaj przyjętego) i inny cytat z Księgi Izajasza, który tak u niego brzmi: „Exsultent coeli desuper, et nubes induant iustitiam, aperiatur terra et pullulet Salvator. Ego enim Dominus Deus creavi Eum" ". Przy całym szacunku do natchnionego tekstu proroka trzeba przyznać, że w nadchodzącej wówczas dobie sporów chrystologicznych tekst ten, bez należytego wyjaśnienia, mógł być i może był ważkim argumentem w ręku tych, którzy chcieli w Chrystusie widzieć byt stworzony. Indicativus perfecti od czasownika creare mógł oddziaływać na wyobraźnię uczestników dysput o wcieleniu Syna Bożego i jego pochodzeniu. Laktancjusz podkreśla zdecydowanie, że Chrystus przybył na ziemię, według słów proroka, jako Syn Człowieczy, „ut ostenderet, quod carne haberet indui in terra, ut suscepta hominis fiugra et conditione mortali doceret homines iustitiam et cum mandatis Dei functus veritatem gentibus revelasset, multaretur etiam morte, ut inferos quoque vinceret ac resignaret atque ita demum resurgens ad Patrem proficisceretur in nube sublatus"10. Również i w następnym rozdziale pisarz stwierdza, że Chrystus narodził się jako człowiek, bo chciał Bóg przez to posłać nauczyciela sprawiedliwości.

Podkreślanie takiego właśnie posłannictwa Syna Bożego, jak widać i z poprzedniego cytatu, ma niewątpliwie związek z tytułem i treścią następnej, V księgi dzieła, zatytułowanej: De iustitia. Laktancjuszowi wyraźnie zależy na tym, by pokazać, że Chrystus w pierwszym rzędzie pragnie, aby zapanowała na Ziemi sprawiedliwość, która jest fundamentem ładu społeczności Kościoła i społeczności państwa. Być może ma to też związek z zaadresowaniem tego dzieła do cesarza Konstantyna, bo właśnie zadaniem władzy cesarskiej jest

\footnotetext{
5 Por. Divinae Institutiones II 10, 3, CSEL 19, 147.

6 Tamże, IV 11, 14, CSEL 19, 309.

7 Por. tamze, IV 12, 5-6.

8 Tamże, IV 12, 6, CSEL 19, 311.

9 Tamże, IV 12, 9, CSEL 19, 311-312.

10 Tamże, IV 12, 15, CSEL 19, 313.
} 
dbałość o to, by w państwie panowała sprawiedliwość. W rozdziale trzynastym IV księgi znajdują się jednak dwa stwierdzenia, które w odniesieniu do nauki o wcieleniu Syna Bożego mogą budzić poważniejsze zastrzeżenia. Otóż podkreśla nasz autor, że Chrystus ,sine patris officio virginali utero procreatus est, ut mediam inter Deum et hominem substantiam gerens nostram hanc fragilem imbecillemque naturam quasi manu ad immortalitatem posset educere" ${ }^{11}$. Wkrótce potem dodaje: „Interim et Deum fuisse et hominem ex utroque genere permixtum prophetis vaticinantibus discimus"12. I chociaż konstatuje, że „factus est Dei filius per spiritum et hominis per carnem"13, to przecież nie ulega wątpliwości, że poprzednie sformułowania zawierały bardzo niebezpieczną przesłankę dla późniejszych sporów o dwie natury w Chrystusie, które doprowadziły do definitywnego rozejścia się Kościołów na Soborze Chalcedońskim w 451 roku. Nie przeczuwał pewnie Laktancjusz, do czego może prowadzić takie uproszczone ujęcie problemu boskiej i ludzkiej natury Syna Bożego, a przecież nie była to u niego jedyna kwestia budząca zastrzeżenia w próbie wykładu ortodoksyjnej dogmatyki. Stanowczo zanadto ponosiła go pasja oratorska i ten właśnie sposób podejścia do tak trudnej problematyki, o ile przy krytyce bogów pogańskich był na ogół skuteczny, o tyle przy pozytywnym wykładzie nauki wiary nie tylko, że okazywał się mało przydatny, ale często jeszcze powodował poważne nieporozumienia. Laktancjusz nie zdawał sobie zapewne sprawy, że materia, którą się zajmuje, nie toleruje przenośni, ozdobnych dodatków i domyślnych uzupełnień, i w tym względzie retoryka zawiodła go na całej linii.

Już w następnym czternastym rozdziale IV księgi, gdy mówi o posłannictwie Chrystusa, jakby zaprzecza pewnym stwierdzeniom z rozdziału trzynastego, a zapewne wiedziony wspomnianym retorycznym zapałem - w każdym razie stawia je w innym świetle, gdy mówi: „Docuit enim [Christus - JW.] quod unus Deus sit, eumque solum coli oportere; nec umquam se ipse Deum dixit, quia non servasset fidem, si missus ut deos tolleret et unum assereret, induceret alium, praeter unum. Hoc erat non de uno Deo facere praeconium, nec eius qui miserat, sed suum proprium negotium gerere, ac se ab eo quem illustratum venerat separare. Propterea quia tam fidelis exstitit, quia sibi nihil prorsus assumpsit, ut mandata mittentis impleret, et sacedotis perpetui dignitatem et regis summi honorem et iudicis potestatem et Dei nomen accepit" ${ }^{14}$. Na pierwszy rzut oka widać, że Laktancjusz zdaje się zapominać o tym, co powiedział w poprzednich rozdziałach, gdzie stwierdzał boskość Chrystusa jeszcze przed jego przyjściem na ziemię. Tu zaś wyraźnie mówi, że Chrystus otrzymał „Dei

\footnotetext{
11 Tamże, IV 13, 4, CSEL 19, 316-317.

12 Tamze, IV 13, 6, CSEL 19, 317.

13 Tamże, IV 13, 5, CSEL 19, 317.

14 Tamże, IV 14, 18-19, CSEL 19, 329.
} 
nomen" wtedy, gdy wypełnił wiernie swoją misję na ziemi. Te i wiele innych podobnych „nieścisłości” nie mogły ujść uwadze teologów, którzy, choć mieli Laktancjuszowi wiele do zawdzięczenia, nie mogli w wielu wypadkach zgodzić się z jego tezami. Nie pomniejsza to faktu, że poruszana przez nas w krótkim rozważaniu problematyka wcielenia Syna Bożego zyskuje w Laktancjuszu kolejnego komentatora, którego głos ma niewątpliwie swoje znaczenie. Jedno z najtrudniejszych zagadnień, które doprowadziło do dramatycznych rozłamów w Kościele, było, rzecz oczywista, żywo dyskutowane, a w tej dyskusji padały głosy bardzo różnorodne. Jeśli weźmiemy to pod uwagę, to reakcja wywołana pewnym sformułowaniami Laktancjusza, przy całym krytycznym ustosunkowaniu się do nich, nie będzie już tak ostra, a pożytek wynikający $\mathrm{z}$ lektury jego dzieł okaże się cennym w dalszych badaniach tego zagadnienia.

\title{
DE LACTANTIO INCARNATIONEM CHRISTI IN DIVINARUM INSTITUTIONUM LIBRIS ASSERENTI
}

\author{
(Argumentum)
}

Quaestio de Dominica Incarnatione iam antiquorum christianorum animos tum movebat tum incitabat, quod hoc vere magnum Mysterium ab illorum temporum hominum mentibus et cogitandi modo plane diuque abhorrebat. Quin immo, discrepantibus virorum doctorum sententiis mox factum est, ut multae eaeque turpissimae haereses orerentur, ambiguis vero enuntiationibus et dictis crebrescentibus haec periculosa et animis vere letalis pestis latius in dies grassaretur.

In Divinarum Institutionum libris Lactantium, qui de omnibus fere gravioribus doctrinae christianae quaestionibus disserere in animo habuerat, hanc quidem praeterire silentio minime conveniebat. Qui dum binam Christi incarnationem quarto praecipue sui operis libro aperte praedicabat, unam scilicet ex Patre, alteram Mariae nomine omisso ex virgine, constanter asserit Christum in carne venisse, ut hominem a potestate diaboli liberaret et mundi redemptor factus illum donaret immortalitate.

Attamen et Lactantii appellationes nonnullos in errorem inducere poterant, praesertim cum et animi scriptoris adfectio et color rhetoricus dubiam auctoris mentem reddidissent. Et quamquam legentibus attendendum est, ne Lactantianae opinioni plus quam iustum exigat et aequum tribuatur, nihilominus illam ad dilucidandam illorum temporum de Incarnatione Domini doctrinam haud minimum contulisse libentissime profitemur. 